\title{
Problems in teaching debate
}

\section{G. Rowland Collins}

To cite this article: G. Rowland Collins (1921) Problems in teaching debate, Quarterly Journal of Speech, 7:3, 261-271, DOI: 10.1080/00335632109379340

To link to this article: http://dx.doi.org/10.1080/00335632109379340

\section{曲 Published online: 05 Jun 2009.}

Submit your article to this journal $2 \pi$

Џll Article views: 5

Q View related articles ¿ 


\title{
PROBLEMS IN TEACHING DEBATE
}

\author{
G. ROWLAND COLLINS \\ New York University
}

N these days of uncertain educational values, it is a pleasure to 1 be teaching an elective course in debate. Occasionally, it is true, one is forced to repel the attacks of curriculum reformers and manipulators, but seldom is he obliged to defend his course and its worth against the questionings of the undergraduate. There is no need for the teacher of debate to explain at length that the sole value of his course is in its training in mental discipline, and explanation which seldom fails to kill all interest in the subject on the part of $75 \%$ of all the members of the class. The students who elect work in debate are certain of the practical valtue of the course. They realize that training in debate is a practical preparation for a life of good citizenship. For all of which teachers of debate may well be thankful.

Most teachers realize the possibilities the subject offers in training for life, and aim "to make college debating more directly identical in character with the actual debating of practical life." An increasing effort is being made to break away from what is purely academic and to connect up college work in debate with the best work of this kind in life-in law, in politics, in business, in any field of life where ideas are attacked and defended. In this attempt. to make debate more than a mere course in mental gymnastics many new problems have come into being.

To me, three of these problems have seemed particularly important. Two of them are actual teaching problems which have to do with methods. The third is not a problem in teaching, but it is a none the less important problem.

The first problem is what I shall call the problem of Imaginative and Suggestive Presentation. The application of the principles of psychology to the teaching of debate is a comparatively new thing. The work of Professor Covington. Professor Woolbert and others has made a valuable contribution to the material of presentation. 
The use of imagination and suggestion in debate has opened up new possibilities to the progressive teacher. What use shall he make of these new ideas? How much class-room time can he afford to give to them? Can any of the present conventional stress on pure logic be omitted? These are questions which present themselves almost immediately.

At the outset, it must be remembered that the time allowed for a course in debate is short, too short, in fact. Time then will not permit the introduction of a mass of psychological material without the sacrifice of much of the logical. That is certain.

Then, too, if you stress, even in a small degree, the importance of imagination in argument, the place of feeling in debate, the emotional appeal, the tendency on the part of your students will be to give you nothing but pictures, images and elaborate word paintings. The inevitable tendency will be for your students to stop presenting facts and solid proof. and to depend upon mirroring or imaging their reasons. Why? Because the use of facts and solid proof means hard and disagreeable work, while the free and riotous use of the imagination is a pleasure. Now do not misunderstand me. I do not believe that one should adhere so rigidly to the traditional logical subject matter as to stifle every bit of creative imagination in the student. Not at all. The point is simply that I have found by actual experience that students will overemphasize the importance of imaginative and suggestive presentation if they are allowed anything like free rein.

I realize, of course, that the appeal to the "intellect", and the appeal to the "emotions" are both needed in effective persuasion. In the words of the psychologists, an effort should be made to get both an open response and a hidden response. In the past our college training in debate has not given enough attention to the "open level" appeal. But in the future, however, we must be careful not to give too much attention to it. Because of the newness and the attractiveness of the psychological material, there is danger that teachers will rush from one extreme to the other. Both "intellectual" and "emotional" appeals are necessary. It is, however, easier to develop the "emotional" appeal than the "intellectual" appeal. In fact, it is very difficult to hold the young debater down to sanity in the use of the "emotional" appeal. If it is easier to develop one 
type of appeal without the other, we need to be particularly careful not to overemphasize that type of appeal which is more easily developed.

If then, the tendency on the part of the students is to let creative imaging replace logical thinking and solid research, it is well for the teacher not to minimize the attention paid to the traditional fundamentals. I believe with Ex-President Foster of Reed College, that "imperfect analysis and unsupported assertion are the two great weaknesses of argumentation." Anything which tends to encourage these two weaknesses needs to be handled with creat care. Our first duty in the short time at our disposal is to teach the fundamentals, to train the student in sound logical thinking and painstaking research.

But let us suppose that the course in Debate extends throughout the year and that there is sufficient time to emphasize the work in Imaginative and Suggestive Presentation. Even then. I am still to be persuaded that a great amount of training in getting emotional responses will be of any direct benefit to the student when he goes out into the world. Now I most certainly realize the value of the emotional appeal to what is commonly called the popular audience. But I ask you, how many of your debating students will have to deal with the popular audience in life? In nine cases out of ten in actual life, the college trained debater will deal not with the popular audience, but with an audience composed of men of his own kindanalytical, keen-thinking men who want to be shown the truth or falsity of a proposition by logical reasoning backed up by tested evidence. To such an andience attempts to image and suggest will be perfectly obvious appeals and will be brushed aside as unworthy of influencing judgment.

Suppose the college debater goes into business. What is the demand there? He must debate across the directors' table and in the committee room. He must prove by sound logic, facts and statistics. He must present his material in a very short time. $\mathrm{He}$ cannot stop long to image his reasons and to suggest associations. He must use his time to present the "meat" of his case. The one man in business who might be said to need training an imaginative and suggestive presentation is the advertising man. In this connection, however, is it not significant that one of the largest adver- 
tising agencies in the United States has recently announced that hereafter it will write only what is called in the language of adve: tising "long circuit" or "reason-why" copy. It has reached the conclusion that "short circuit" emotional copy does not pay the adver. tiser. The demand in business is more and more for sound logical reasoning backed up by tested evidence.

Now let me make myself clear. I recognize the value of Imaginative and Suggestive Presentation, but $I$ believe that the appeal in such presentation is to the popular audience principally. I am asking whether or not the popular audience actually exists for the debater in real life. How often do popular audiences gather to hear a pro and con discussion? The public lecture is still in demand, but the public lecture that is demanded is not one that seeks to persuade, but one that seeks to entertain. Popular audiences do come together for entertainment, but training to speak before such audiences is surely not the work of a course in debate. In the great majority of cases debating in life is carried on before small groups of pcople who want to hear in the shortest possible time the strongest possible case presented as regards reasons and facts. There is little time and little need for imaging. If the facts are presented the conclusion will be accepted.

Occasionally, of course, debates do take place in actual life before large popular andiences. Not more than two weeks ago I attended such a debate in the Lexington Avenue Theater in New York on the subject of the Open z'c. the Closed Shop. The audience was largely made up of workers, members of trades unions. They were bitterly prejudiced against the Open Shop. The speaker for the Closed Shop used a picturing, imaging, emotional appeal throughout. His words were received with wild applause. He did not need to use logical reasoning or cumulative evidence. The majority of the audience were in sympathy with his case. On the other hand, the speaker for the Open Shop used no emotional appeal, but based his entire case on analytical reasoning, backed up by facts. The task of persuading that prejudiced audience to accept the principle of the Open Shop was an impossible one, but the speaker did make a decided impression upon the unionists. Expressions of respect for his reasoning ability were heard on every side as the audience left the theater. That speaker would prob- 
ably have made no impression whatever if he had used an emotional appeal. That popular audience would have seen through such an attempt in an instant. The Closed Shop speaker could use Imaginative and Suggestive Presentation because the majority of the audience had already made its decision. The Open Shop speaker by straight argument shook the beliefs of the prejudiced and probably persuaded every unprejudiced person in the andience. The Closed Shop speaker entertained his audience and little more. The Open Shop speaker faced the hardest kind of a debating problem, the prejudiced audience, and he made an impression upon it.

These then are my views on the problem of what to do with matters of Imaginative and Suggestive Presentation in a course in debate. I believe that we should not omit consideration of the new material that is being given us by the psychologists, but that we should be very careful to see to it that our consideration of this material does not force us to minimize solid training in logical reasoning, briefing, and the use of evidence. I believe that in the debating of actual life there is no great need for imaginative reasoning and the emotional appeal. I believe that if we emphasize Imaginative Presentation to the detriment of analysis, classification, and logical synthesis, we are catering to the development of that American credulity which Dr. Eliot has so recently attacked. We are encouraging the herd impulse, the common emotion response. -We are not doing what we should do to train our students in straight thinking and hard work.

The second teaching problem which has seemed important to me is the problem of extempore speaking in debate. Here, also, I believe that a word of caution is necessary. Many, many sins have been committed in the name of extempore debating. My own experience has been so definite that I am entirely persuaded that as for me, the problem is not how to develop extempore debating, but how to suppress it. Extempore debating for the undergraduate usually means extempore thinking. It places a premium on wordiness and superficiality. It brings to the fore the man who can talk long and say little. To me, one of the greatest obstacles to the progress of speech education in dehate, is the continual spouting deluge of words which pours forth from the mouth of the shallow extenpore debater. 
I believe that we need to get right down to bed rock to examine our ideas as to extempore speaking in debate. We say that we are all agreed that extempore rebuttal is the thing to strive for. When pressed we admit that extempore rebuttal is not good unless it cuts straight through the non-essentials to the heart of the question at issue. Honestly and frankly, how many extempore debaters have you heard who could produce stuch a rebuttal? Have you ever heard an extempore rebuttal in which there was not a great mass of verbiage, and which would not have henefited greatly by revision? Lately I have been wondering whether or not our reverence for extempore speaking in general is not based upon the faulty belief that we often hold in regard to writing. I refer to the idea that speed and facility are the prime requisites-to the impression that if a thing is quickly done it is well done. I am very much afraid that it is because we teachers conscious or unconsciously hold the pestilent notion that the finest productions of the mind are the fruits of sudden inspiration, the chance visitations of a fortunate moment, the flashings of intuition, that so many people are at all times ready to mount the platform and afflict the public with "great mouthfuls of spoken wind."

But you may say, "You are not talking about true extemporc debating; you are talking about impromptu debating. Extempore speaking in debate presumes serious preparation." True extempore speaking in debate does imply preparation. But even with that preparation, if thought is not given to the exact word expression of the ideas, is it possible to approach maximum effectiveness? I say No, decidedly. I have had debaters prove it to me time and time again. Take your ablest debater, have him study a proposition for a month, and then ask him to give you some extempore rebuttal on a certain point. His first attempt will he a scattering, wordy, ineffective talk. Then send him out of the room and tell him to think over what he has said. Tell him that you will hea: his rebuttal again in a few minutes, but that you are going to cut down his time of speaking exactly one half. After ten or fifteen minutes, call him back into the room and ask him to refute the same point. You will find that his second talk will be at least I00\% more effective than his first, though given in half the time. What has happened? Your debater has thought out the word ex- 
pression of his ideas. He has written the words down in his mind and memorized them more or less. Now ask him to write out a refutation of the same point, striving for clearness and power. Have him read the written material over two or three times, then ask him to deliver this refutation, and you will have the greatest possible effectiveness from that spcaker. Have him go through the same process on all the important points. Instead of making him entirely dependent upon sudden inspiration, this sort of practice makes him an effective debater. In the actual debate, only a few extempore connecting and adjusting sentences are necessary. The result is a refutation which seems spontaneous, a refutation which wastes not a word nor a second, a refutation which is effective.

But what about extempore debating in actual life? It is my contention that seldom do you have extempore speaking in the debates of actual life. A man is almost never asked to speak for $\mathrm{cr}$ against a proposition about which he knows little. And no matter how well informed the speaker may be, seldom does he come tc his talk without first thinking over exactly what he is going to say. Perhaps he does not actually write the words down on paper, and memorize them from it, but he usually delivers the talk over and over again to himself so many times that he has done almost the same thing-he has planned the word expression of his thoughts and memorized phrases and sentences. I firmly believe that the debater should pay definite attention to the phrasing of his ideas in advance of his talk. Revision makes for true effectiveness. While some of the clergymen of New York City twitter extemporaneously through forty minutes to establish their points to empty pews. others move thousands with the force of their expressed thoughts even though they are confined to the manuscript in delivery.

Truly the teacher of debate needs to be careful not to give extempore speaking undue emphasis. I believe that the reason many of us devote so much time to extempore debating is becatse we are downight lazy as teachers, and that the reason so many of our students praise the extempore work is because they are downright lazy as students. It is easy to use the class hour in extempore work. It is easy to keep the interest of the students by extempore 
work in a great variety of subjects. The variety appeals. But surely we teachers of debate cannot do the easy think only and long hold our self-respect.

I believe that each student should be given one proposition each semester, and one proposition only. I believe that he should work out a thorough argument for and against that proposition. His arguments should be revised again and again, until they are made as nearly perfect in effectiveness as is possible. I believe that the instructor should work with the student, that he should investigate for himself and not merely act as a judge on what the student discovers. I believe that the instructor should suggest various methods of approach, various possibilities of arrangement, and that in every case the different methods of handling the material should be tried out on the class as a whole. I believe that the student should debate his proposition, formally, at least three times, each time, if possible, before different sections of the class. This means time and work on the part of the teacher, but if the course in de. bate is not worth time and work, it is not worth teaching.

Let me call your attention to anther problem, a problem that is not one in teaching methods. It is, however, one upon which I feel very strongly, and one which, in my opinion, is worth an, entire paper in itself. It is this, what should be the relation of the teacher of debate to the college or university intercollegiate debating teams? Here is a question that many teachers of debate try to dodge. May I say that I do not believe that one can simply dismiss the problem with the remark that intercollegiate debating is a student matter. I believe that the teacher of debate must take an active and interested part in the coaching of the intercollegiate debating teams. Debating and the teaching of debate is being dis. credited to-day by the frightful exhibitions of andirected intercollegiate debating which are so common.

Intercollegiate debating at present is not performing its true function. Right here let me qrote from an exceedingly fair statement of the matter by Professor O'Neill.

'Foth for those who participate and those who listen, contests in debate should be helpful toward higher standards, better ideals. greater ability in this field. *** Their function is properly educational, and they should not be allowed to be diverted from their 
really great educational end. When we neglect their possibilities as educational agencies and prostitute them to mere advertising and cheap 'sporting' ends, we are committing an offense as great as any of the outrages that characterized the worst days of athletic rivalry. Now it is only by making them approximate as nearly as possible in character and conduct, the best debates of actual life that we can hold them true to this educational purpose."

Are the intercollegiate debates of the present setting higher standards? I must confess that I doubt it. What is the present status of intercollegiate debating? In many of our eastern colleges and in at least two of the first universities of the nation, the contro: of intercollegiate debating is entirely in the hands of the students. What is the result? A proposition is decided upon about two or three weeks in advance of a good date. The teams prepare as best they can possibly with the assistance of a graduate debater who happens to be in the neighborhood. The debate takes place, and consists of challenges, assertions, and facetious rebuttal. The delivery is conversational. Yes, hut stumbling and haltung-nerveracking to the listener.

During the present year New York University received a challenge to debate within two weeks time the proposition: Resolved, that the United States should invite the A. B. C. powers to cooperate in establishing a joint protectorate over Haiti. I submit that it is impossible for students to prepare a worthwhile debate on such a proposition in two weeks and at the same time keep up in their class-room work, and carry on the other outside activities in which they may be engaged. It happens that our intercollegiate bebating squad has been working on the Haitian question for 3 months, and I do not consider that we are too ready to debate it even now.

Again, under student control, there is continual bickering and jockeying to gain advantages in wording and detining the proposition. This year. in what should be the most notable triangular debating arrangement of the United States, a misunderstanding of definition came up but three or four days before the actual debate. The proposition debated was the general subject of the Open vs. the Closed Shop. To gain desired advantages over certain opponents the student debating committee of the university whose 
duty it was to word the proposition, framed it negatively: Re. solved, that the employers of the United States should abandon the principle of the open shop. By the definition of the term "open shop" the issues were entirely changed so that the proposition came down to this: Resolved, that the employers of the United States should abandon the principle of not recognizing the trade unions. The inevitable result of this sort of thing is a debate in which there is little real clash, and in which there is an unpleasan: squabble over definitions to the discomfiture of a badly confused attience.

Do such contests set before those who hear them the good examples of public discussion which Professor O'Neill says that they should? Hardly, and if these contests continue to be the rule, it will be but a short while before no one will come to hear them. Of late, debates before an audience which is composed of three judges, two alternates, and a few stragglers have been all too numerous.

The development of the twenty-four hour debate and its control by the students has not helped matters any. I have heard a number of twenty-four hour debates, but I have yet to hear one in which there was any direct clash, any effective, debating. In almost every case the issues were clonded by the ignorance of the debaters. I am tempted to be concrete again. Within the present month a twenty-four hour intercollegiate debate was held in $\mathrm{New}$ York City on the proposition: Resolved, That Labor Unions be exempted from Anti-Trust Legislation. Now it happens that the Supreme Court of the United States in January of this year $d^{\circ}$ cided in the Duplex case, that the Clayton Act does not exempt Labor Unions from Anti-Trust Legislation. One of the teams debating in this debate knew nothing of the Duplex case, and the other knew so little about it that any effective use of it was impossible. Throughout the evening the following phrase was bandied from one side to the other: "The burden of proof is not upon us for we uphold the status quo." Both teams upheld the status quo and both teams were ignorant of what the status quo was. The phrase status quo became a signal for laughter on the part of the audience. It laughed at the absurdities of reasoning, and at the feeble attempts at refutation. Such a condition is not a healthy one 
for intercollegiate debating, particularly when the spectacle is staged by two of the leading universities in the east.

The responsibility for the standards maintained in intercollegiate debating is ours-as teachers of debate. I know that there is no harder work than honestly coaching an intercollegiate debating squad. It is easy to dodge that work, but as teachers in the particular field we cannot afford to dodge it. We cannot meet the men once or twice, give them a few suggestions and let it go at that. We must buckle down and work with them. We must see to it that the man who represents the practice of the art we are teaching, is capable of doing it creditably. We must set standards and adhere to them. Our work is largely judged, whether we will or no, by the showing of the intercollegiate debaters. How many people in the audience or in the university know whether or not we have had any hand in coaching the team? The supposition is that we have. How many people know whether or not a certain debater has taken our course in debate? The supposition is that he has. In self protection it behooves the teacher of debate to realize the proper relation to intercollegiate dehating. Let us not shirk, but put our hands to the task and saw wood. 